\title{
Studi Docking Molekuler Senyawa Dalam Minyak Atsiri Pala (Myristica fragrans H.) Dan Senyawa Turunan Miristisin Terhadap Target Terapi Kanker Kulit
}

\author{
Study of Molecular Docking Compounds of Nutmeg Essential Oils (Myristica fragrans H.) and Compound \\ of Myristicin Derivatives Against Skin Cancer Therapy Targets
}

\author{
Alfian Bagas Pratama*, Rina Herowati, Hery Muhamad Ansory \\ Fakultas Farmasi, Universitas Setia Budi, Surakarta \\ Corresponding author: Alfian Bagas Pratama; Email: alfian.bagas1998@gmail.com \\ Submitted: 01-09-2020 Revised: 04-01-2021 \\ Accepted: 25-01-2021
}

\begin{abstract}
ABSTRAK
Kanker kulit adalah penyakit di mana kulit kehilangan kemampuannya untuk regenerasi dan tumbuh secara normal. Penyebab umum terjadinya kanker kulit adalah intesitas paparan sinar UVB. Penelitian terdahulu telah membuktikan kandungan senyawa di dalam minyak atsiri pala (Myristica fragrans $\mathrm{H}$.) khususnya miri stsin memiliki khasiat sebagai antioksidan dan efek cytotoxic. Telah dilakukan skrining target molekuler dari kandungan kimia minyak atsiri pala beserta turunan miristisin-nya terhadap target molekuler antikanker kulit antara lain Heat Shock Protein 90 (HSP90A), Prostaglandin Synthase 2 (PTGS2) dan Dihydroorotate Dehidrogenase (DHODH), dan memprediksi interaksi senyawa dari ke 61 ligan uji dengan target molekuler tersebut, kemudian dilakukan docking molekuler menggunakan perangkat lunak PyRx 0.8. Hasil penelitian menunjukkan bahwa senyawa dalam minyak atsiri pala yaitu Guanicin memiliki nilai $\Delta \mathrm{G}_{\text {bind }}$ yang baik pada HSP90A dengan nilai -8,2 kkal/mol. Hasil docking antara protein PTGS2 dan DHODH dengan ligan baik dari senyawa dalam minyak atsiri pala maupun senyawa turunan miristisin menunjukkan bahwa hampir semua ligan dapat berinteraksi dengan kedua target dengan ligan yang nilai $\Delta G_{\text {bind }}$ paling kecil dan memiliki model interaksi terbaik dari senyawa minyak atisi pala adalah asam dihidroguaiaretik, dengan nilai $\Delta \mathrm{G}_{\text {bind }}$ secara berurut-urut sebesar $-8,1 \mathrm{kkal} / \mathrm{mol}$ dan $-9,3 \mathrm{kkal} / \mathrm{mol}$.
\end{abstract}

Kata kunci: kanker kulit; minyak atsiri; Myristica fragrans $\mathrm{H} . ;$ docking molekuler

\section{ABSTRACT}

Skin cancer is a disease in which the skin loses its ability to regenerate and grow normally. A common cause of skin cancer is the intensity of UVB exposure. Previous research has proven the content of compounds in nutmeg essential oil (Myristica fragrans $\mathrm{H}$.) especially myristicin has antioxidant properties and cytotoxic effects. Molecular target screening of the chemical content of nutmeg essential oil and myristicin derivatives for molecular targets of skin cancer was included Heat Shock Protein 90 (HSP90A), Prostaglandin Synthase 2 (PTGS2) and Dihydroorotate Dehydrogenase (DHODH), and interaction were predicted of the 61 test ligands with these molecular targets, then molecular docking is done using PyRx 0.8 software. The results showed that the compound in nutmeg essential oil namely Guanicin had value $\Delta \mathrm{G}_{\mathrm{bind}}$ is good at HSP90A with a value of $-8.2 \mathrm{kcal}$ / mol. The docking results between PTGS2 and DHODH proteins with ligands from both compounds in nutmeg essential oil and myristicin derived compounds showed that almost all ligands can interact with both targets with ligands with the lowest $\Delta \mathrm{G}_{\text {bind }}$ value and have the best interaction model of nutmeg atisi oil compound is dihydroguaiaretic acid with $\Delta \mathrm{G}_{\text {bind }}$ values of $-8.1 \mathrm{kcal} / \mathrm{mol}$ and $-9.3 \mathrm{kcal} / \mathrm{mol}$.

Keywords: Skin cancer; essential oils; Myristica fragrans H.; molecular docking

\section{PENDAHULUAN}

Kulit manusia berulang kali terkena radiasi ultraviolet yang mempengaruhi fungsi dan kelangsungan hidup berbagai jenis sel dan dianggap sebagai faktor penyebab utama dalam induksi kanker kulit (D'Orazio et al., 2013). Hal tersebut dapat diartikan penyebab bahwa kanker kulit adalah seringnya terkena sinar matahari yang mengandung sinar UV. Negara Indonesia adalah negara yang terletak di sepanjang khatulistiwa, yang berarti paparan sinar matahari cukup tinggi di sepanjang tahun.
Penderita kanker kulit di Indonesia cukup besar dimana menempati urutan ke 3 (tiga) dari keseluruhan jenis kanker yang ada di Indonesia. Agusta (2000) mengemukakan kandungan senyawa di dalam minyak atsiri pala (Myristica fragrans H.) memiliki khasiat sebagai antioksidan dan mencegah kanker dalam prosesnya. Minyak atsiri pala menghentikan pembentukan pembuluh darah tertentu yang memberi asupan makan tumor (antiangiogenik). Dalam penelitian Suthargar et al., (2012) membuktikan bahwa minyak atsiri pala 
memiliki aktivitas antiangiogenik yang potensial, miristisin dilaporkan menginduksi sitotoksisitas pada sel neuroblastoma SK-NSH manusia melalui mekanisme apoptosis pada sel melanoma manusia, disamping itu eugenol yang merupakan salah satu komponen dalam minyak atsiri juga menunjukan efek pemicu apoptosis.

Tujuan penemuan obat adalah untuk mengidentifikasi, menoptimalkan dan memvalidasi secara klinis senyawa-senyawa yang mengikat dan memodulasi fungsi protein target yang terlibat dalam terjadinya penyakit (Fang et al., 2016). Metode analisa bioinformatika dapat digunakan untuk membantu proses identifikasi target dengan docking molekuler. Dengan membandingkan kemiripan struktur senyawa uji terhadap kumpulan senyawa yang diketahui targetnya dalam satu atau lebih database maka diprediksi makromolekul mana saja yang berpotensi sebai target. Analisis docking memungkinkan identifikasi awal terhadap molekul target yang berpotensi sebagai agen antikanker dari senyawa alami. Analisis docking memungkinkan untuk mengetahui model pengikatan yang terjadi sehingga dapat digunakan untuk memastikan fungsinya sebagai agen antikanker (Phosrithong \& Ungwitayatorn 2010).

Pengenalan makromolekul target dan mekanisme kerja dari suatu senyawa aktif dapat mempermudah optimasi aktivitas. Jika target kerja suatu senyawa dalam memberikan efek farmakologis telah diketahui, selanjutnya dapat dilakukan optimasi aktivitas obat yang terarah berdasarkan pola interaksi obat-target (Young et al., 2007). Tantangan yang dihadapi untuk menentukan target tertentu dari suatu senyawa aktif adalah proses pengujiannya yang panjang dan membutuhkan biaya yang besar karena harus menguji satu senyawa ke banyak makromolekul. Salah satu cara untuk menjawab tantangan tersebut adalah dengan metode in silico yaitu docking molekuler. Dengan membandingkan kemiripan struktur senyawa uji terhadap kumpulan senyawa yang diketahui targetnya dalam satu atau lebih database maka dapat diprediksi makromolekul mana saja yang berpotensi sebagai target. Hasil dari prediksi ini selanjutnya dapat diujikan lebih lanjut dengan docking molekuler untuk melihat model interaksinya. BATMAN-TCM (Bioinformatics Analysis Tool for Molecular mechanism of Traditional Chinese Medicine), Swiss Target Prediction, KEGG (Kyoto Encyclopedia of Genes and Genomes) merupakan beberapa alat bioinformatika yang dapat digunakan untuk mengidentifikasi target dari suatu senyawa aktif (Kong et al., 2017).

Penelitian ini bertujuan untuk mengidentifikasi senyawa dalam minyak atsiri pala (Myristica fragrans H.) dan senyawa turunan miristisin memiliki interaksi yang baik terhadap target molekuler kanker kulit, berdasarkan nilai docking dan pola interaksi.

\section{METODE PENELITIAN \\ Alat dan Bahan}

Perangkat keras yang digunakan adalah komputer Windows 10 pro dengan spesifikasi Intel@ Core $^{\mathrm{TM}}$ i7-3770 CPU @ 340 GHz, RAM 8,00 GB, Sistem operasi 64-bit operating system, prosesor basis x64.

Perangkat lunak yang digunakan adalah ChemDraw 2015, SystemDock, PyRx 0.8 (Sargis Dallakyan, The Scripps Research Institute, Amerika), AutoDock Vina (The Scripps Research Institute, Amerika), Discovery Studio Visualizer v16.1.0.15350 (Dessault Systems Biova Corp 2015), PyMOL Educational (Schrodinger).

61 Struktur dua dimensi ligan senyawa dalam minyak atsiri pala dan turunan miristisin yang digambar menggunakan program ChemDraw ulta 8.0 dan disimpan dalam format. mol2. Struktur makromolekul yang digunakan dalam pengujian ini diunduh dari Protein Data Bank (PDB) melali situs http://www.rcsb.org/, yaitu HSP90A (Code PDB: 2VCJ), PTGS2 (Code PDB: 5IKQ) dan DHODH (Code PDB: 2BXV).

\section{Jalannya Penelitian \\ Pemilihan Target \\ Target dipilih berdasarkan kategori penyakit pada hasil BATMAN-TCM, hanya protein yang berperan pada penyakit kanker kulit. Struktur makromolekul yang digunakan dalam pengujian ini diunduh dari Protein Data Bank (PDB) melalui situs http://www.rcsb.org/.}

\section{Cara Kerja Docking Molekuler}

Pengunduhan Makromolekul

Protein yang berperan pada kanker kulit akan diunduh strukturnya dari Protein Data Bank (PDB) melalui situs http://www.rcsb.org/.

\section{Pembuatan Struktur Tiga Dimensi Ligan Uji}

Struktur dua dimensi dari ligan uji dibuat menggunakan perangkat lunak ChemDraw ultra 8.0, kemudian di konversi ke model 3D dengan 
Tabel I. Struktur makromolekul yang terpilih

\begin{tabular}{|c|c|c|c|c|}
\hline & Code & Tipe & Kode PDB & Ligan \\
\hline Heat Shock Protein 90 & HSP90A & Chaperone & $2 \mathrm{VCJ}$ & $\mathrm{C}_{23} \mathrm{H}_{24} \mathrm{ClN}_{3} \mathrm{O}_{5}$ \\
\hline Prostaglandin synthase 2 & PTGS2 & Oxireductase & $5 \mathrm{IKQ}$ & $\mathrm{C}_{14} \mathrm{H}_{11} \mathrm{CI}_{2} \mathrm{NO}_{2}$ \\
\hline $\begin{array}{l}\text { Dihydroorotate } \\
\text { dehidrogenase }\end{array}$ & DHODH & Oxireductase & $2 \mathrm{BXV}$ & $\mathrm{C}_{20} \mathrm{H}_{15} \mathrm{~F}_{4} \mathrm{NO}_{4}$ \\
\hline
\end{tabular}

Chem3D Ultra 8.0. Struktur 3D disimpan dengan format PDB file. Struktur 3D kemudian di optimasi menggunakan VegaZZ, kemudian disimpan dengan format.mol2.

\section{Preparasi Makromolekul}

Makromolekul yang telah diunduh terdapat interaksi ikatan hidrogen dengan jembatan air, sehingga air yang terlibat dalam interaksi dihapus, kemudian dilakukan optimasi dengan AutoDockTools. Optimasi yang dilakukan antara lain penghilangan rantai yang tidak diperlukan, penambahan hidrogen dan penambahan muatan Kollman.

\section{Preparasi Ligan}

Struktur tiga dimensi dibuka dengan program VegazZ lalu ditambahkan atom hidrogen. Senyawa diperbaiki muatannya dengan menambahkan muatan parsial forcefield autodock kemudian senyawa diminimisasi sebanyak 10.000 langkah untuk memperoleh konformasi yang paling stabil kemudian disimpan dalam format .mol2.

\section{Validasi Docking Molekuler}

Validasi metode docking terhadap ligan asli dilakukan untuk mencari konformasi ligan asli. Konformasi hasil docking yang diperoleh selanjutnya disejajarkan dengan konformasi ligan asli kristalografi yang dinyatakan dalam nilai RMSD. Pengaturan gridbox pada proses docking digunakan untuk menentukan ruang berikatan ligan yang akan di-docking. Gridbox dilakukan dengan menrujuk kepada ligan yang sudah berikatan dengan makromolekul protein pada saat diunduh.

\section{Proses Docking Molekuler}

Proses docking molekuler menggunakan PyRx 0.8 dengan sistem Autodock Vina. Struktur makromolekul dan ligan yang telah dioptimasi secara terpisah dalam satu folder yang sama. Proses docking molekuler dilakukan dengan menggunakan gridbox dan parameter minimisasi energi sesuai hasil validasi.

Visualisasi Data

Data yang telah didapatkan dari proses pengunduhan yang akan digunakan untuk tahap preparasi, optimasi geometri, minimisasi energi dan penambatan molekul ditampilkan dengan menggunakan program berbasis visualisasi yaitu Discovery Studio Visualizer dan Pymol.

\section{HASIL DAN PEMBAHASAN}

Hasil prediksi target molekuler dengan BATMAN-TCM menunjukkan sebagian besar kandungan $M$.fragrans diprediksi aktif terhadap protein target antikanker oleh BATMAN-TCM seperti yang terlihat pada tabel I.

Penyiapan struktur makromolekul yang digunakan akan menentukan prediksi interaksi yang terjadi. Pada tahap ini, struktur tiga dimensi dari setiap protein target dicari menggunakan UniProt. Terdapat tiga protein target (HSP90A, PTGS2, dan DHODH) yang memnuhi kriteria antara lain memiliki struktur tiga dimesi hasil $x$-ray difraction karena dapat diaplikasikan untuk struktur makromolekul yang besar ( $>100 \mathrm{Kda})$ serta lebih presisi dan terkompleks dengan ligan asli yang memiliki aktivitas yang diperkirakan sama dengan ligan uji. Organisme yang digunakan sebisa mungkin adalah makromolekul pada manusia (homo sapiens) atau hewan yang mendekati dengan makromolekul manusia, namun sering kali kode makromolekul terpilih tidak memuat informasi tentang makromolekul pada manusia sehingga sumber makromolekul digunakan dari organisme selain manusia.

Dan dilakukan preparasi menggunakan aplikasi AutoDock Tools. Preparasi ini bertujuan untuk menghilangkan senyawa-senyawa non residu asam amino, molekul air. Selain penghilangan senyawa-senyawa tersebut, optimasi makromolekul dilanjutkan dengan menambahkan hidrogen dan muatan Kollaman. 


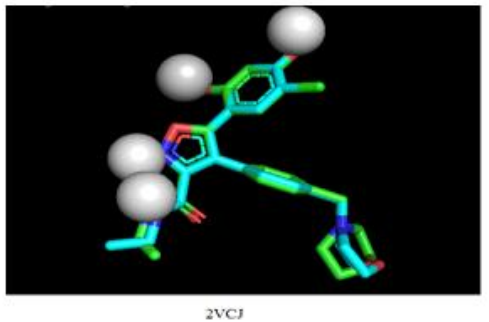

A

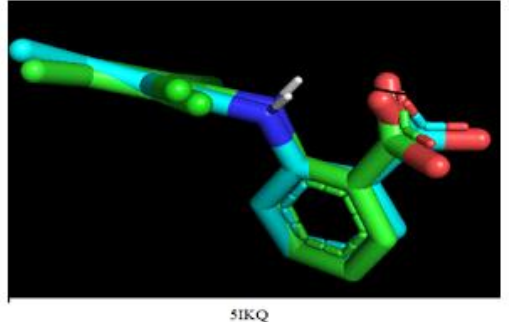

B

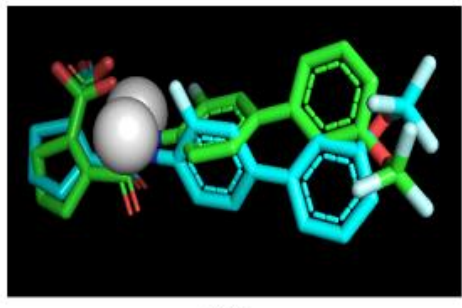

$2 B \mathrm{XV}$

C

Gambar 1. A. Hasil validasi metode docking makromolekul 2VCJ dengan Pymol; B. Hasil validasi metode docking makromolekul 5IKQ dengan Pymol; C. Hasil validasi metode docking makromolekul 2BXV dengan Pymol

Tabel II. Pengaturan grid center dan dimensi gridbox

\begin{tabular}{|c|c|c|c|c|c|c|}
\hline \multicolumn{7}{|c|}{ Gridbox } \\
\hline & \multicolumn{3}{|c|}{ Center } & \multicolumn{3}{|c|}{ Dimensi (Å) } \\
\hline Makromolekul & $\mathbf{X}$ & $\mathbf{Y}$ & $\mathbf{Z}$ & $\mathbf{X}$ & $\mathbf{Y}$ & $\mathbf{Z}$ \\
\hline $2 \mathrm{VCJ}$ & 31.5465 & 8.6755 & 26.7956 & 25 & 25 & 25 \\
\hline 5IKQ & 22.4306 & 51.9255 & 17.4050 & 25 & 25 & 25 \\
\hline $2 \mathrm{BXV}$ & 38.8822 & 44.2740 & 42.8148 & 25 & 25 & 25 \\
\hline
\end{tabular}

Menurut Drie (2005) penambahan atom hidrogen (protonasi) bertujuan untuk menyesuaikan suasana docking agar mendekati $p H$ fisiologis. Hasil optimasi disimpan dalam format .pdbqt.

Makromolekul yang telah dioptimalkan kemudian dilakukan uji pendahuluan dan validasi metode menggunakan aplikasi PyRx (Dallakyan \& Olson 2015). Validasi metode docking dilakukan pada ligan asli yang telah diekstrak dari makromolekul dan dioptimasi menggunakan VegaZZ. Prinsip umum validasi docking adalah dengan mendockingkan ulang ligan asli ke protein targetnya di mana ligan dan protein dipreparasi dengan cara dan parameter docking yang akan digunakan untuk studi docking ligan uji. Sebelum validasi terlebih dahulu dilakukan penentuan pusat dari gridbox berdasarkan pusat dari koordinat ligan asli serta penentuan ukuran gridbox yang didasarkan pada ukuran binding site dan ukuran dari ligan uji. Pusat dari gridbox dan dimensinya tercantum pada tabel II.

Parameter pada validasi adalah nilai RMSD. RMSD merupakan nilai yang digunakan untuk menentukan apakah prediksi modus ikatan tersebut berhasil dan penting untuk validasi program docking. Pada umumnya, nilai RMSD dikatakan baik jika $\leq 2 \mathrm{~A}$. Semakin besar penyimpangan, semakin besar pula kesalahan pada prediksi interaksi ligan dengan protein (Brooijmans 2009). Pada penelitian ini pose dan nilai RMSD hasil redocking ligan asli seperti yang ditampilkan pada tabel III dan gambar 1 .

Struktur dua dimensi dari masing-masing ligan dibuat secara manual dengan bantuan aplikasi ChemDraw ultra 8.0 kemudian di konversi ke model tiga dimensi dengan bantuan 
Tabel III. Nilai RMSD ligan aslikristalografi dengan ligan redocking

\begin{tabular}{cc}
\hline Makromolekul & RMSD \\
\hline 2VCJ & 0.003 \\
5IKQ & 0.421 \\
2BXV & 1.733 \\
\hline
\end{tabular}

Tabel IV. Hasil senyawa docking molekuler terhadap protein Hsp90A

\begin{tabular}{lcccc}
\hline \multirow{2}{*}{ Senyawa } & $\begin{array}{c}\Delta \mathbf{G}_{\text {binding }} \\
\text { (kkal/mol) }\end{array}$ & \multirow{2}{*}{ SD } & \multicolumn{2}{c}{ Insteraksi residu AA } \\
\cline { 4 - 5 } & $-9,8$ & 0,1 & Asp93, Thr184, Gly97, & Phe138, Leu107, Met98, \\
Ligan asli & & & Lys58 & Ala55 \\
Guaiacin & $-8,2$ & 0 & Asn51 & $\begin{array}{c}\text { Ser52, Ala55, Met98, } \\
\text { Lys58, Ile96 }\end{array}$ \\
Turunan miristisin 5 & $-7,7$ & 0,1 & Asn51, Thr184, Asp93 & Gly135, Met98 \\
\hline
\end{tabular}

Keterangan: cetak tebal merupakan kesamaan residu asam amino ligan uji terhadap ligan asli

aplikasi Chem3D Ultra 8.0, setelah itu struktur tiga dimensi ligan disimpan dengan format.pdb. Struktur tiga dimensi kemudian di optimasi menggunakan VegaZZ dan disimpan dengan format .mol2. Tujuan dilakukannya optimasi geometri pada masing-masing ligan yaitu untuk menghasilkan energi terendah yang menunjukkan kestabilan struktur kimia ligan yang telah dioptimalkan akan menghasilkan struktur dengan lipatan yang berbeda dengan struktur awal.

Keenam puluh satu ligan di-docking-kan ke 3 target untuk melihat interaksinya dengan masing-masing target makromolekul yang potensial menggunakan aplikasi PyRx. Gridbox yang digunakan adalah gridbox yang pada saat validasi metode, sehingga nilai RMSD tetap dan hasil akan lebih akurat. Analisa hasil docking pada penelitian ini meliputi nilai $\Delta \mathrm{G}_{\text {binding }}$ dan interaksi ligan dengan residu protein. Konformasi masing-masing ligan hasil docking diperingkatkan berdasarkan nilai $\Delta \mathrm{G}_{\text {binding. }}$. Nilai $\Delta \mathrm{G}_{\text {binding }}$ yang kecil menunjukkan bahwa konformasi yang terbentuk adalah stabil, dan sebaliknya bila nilai $\Delta \mathrm{G}_{\text {binding }}$ besar menunjukkan kurang stabilnya komplek yang terbentuk (Fikry 2014).

Berdasarkan hasil docking molekuler dapat diketahui ketiga protein target memiliki nilai $\Delta \mathrm{G}_{\text {binding }}$ yang baik terhadap senyawa dalam minyak atsiri pala maupun senyawa turunan miristisin. Ketiga makromolekul setidaknya memiliki beberapa senyawa dengan nilai $\Delta \mathrm{G}_{\text {binding }}$ yang hampir mendekati nilai ligan asli dan dengan nilai $\Delta \mathrm{G}_{\text {binding }} \geq-7$.

\section{Heat Shock Protein 90A}

Residu asam amino yang terlibat langsung dalam interaksi dengan ATP adalah Thr184, Leu48, Asp93, Asn51, Lys98, dan Gly97. Selain itu, $\mathrm{Mg}^{2+}$ dan beberapa molekul air membentuk interaksi elektrostatik dan ikatan hidrogen masing-masing antara Hsp90 dan ATP. Selain itu, Glu33 diperlukan untuk hidrolisis ATP. Sedangkan pada ikatan non-hidrogen berupa Met98, Leu107, Val150, Phe138, Ala55, Val186, dan Ile96 (Alsaher et al., 2016). Hasil docking terbaik terhadap protein Hsp90A ditunjukkan pada tabel IV.

Guaiacin memiliki $\Delta G_{\text {bind }}$ sebesar $-8,2 \mathrm{kkal} / \mathrm{mol}$ untuk target Hsp90A dan menempati binding pocket yang sama seperti ligan asli hanya saja tidak terdapat ikatan hidrogen dengan Asp93, Thr184, Gly97, Lys58 seperti ligan asli. Pada gambar 2B ditunjukan guaiacin berinteraksi dengan residu secara ikatan hidrogen, walaupun interaksi dengan Asn51 tidak terdapat pada ligan asli, Asn51 juga merupakan salah satu residu pada binding pocket yang berperan dalam penghambatan protein target. Pada residu Ala55 membentuk interaksi Pi-sigma. serta residu Met58 yang membentuk interaksi Pi-sulfur.

Turunan miristisin 5 memiliki nilai $\Delta \mathrm{G}_{\text {bind }}$ sebesar -7,7 kkal/mol, angka tersebut menunjukkan selisih yang cukup jauh dari skor ligan asli tetapi dilihat dari interaksinya dengan makromolekul sebagaimana yang terlihat pada tabel IV dan gambar 2C ditunjukkan bahwa senyawa terunan miristisin ini menempati binding pocket yang sama dengan ligan asli, 


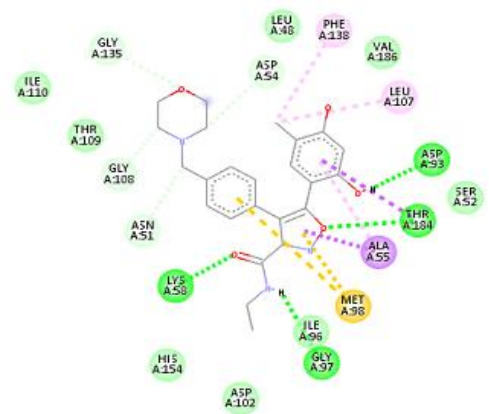

A

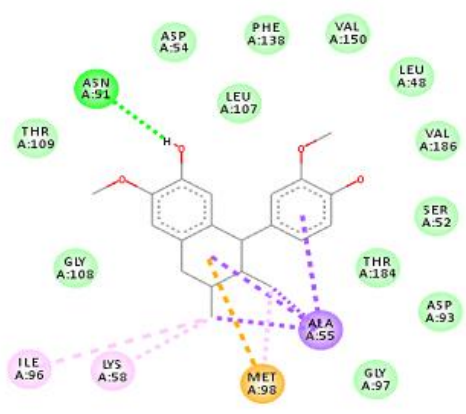

B
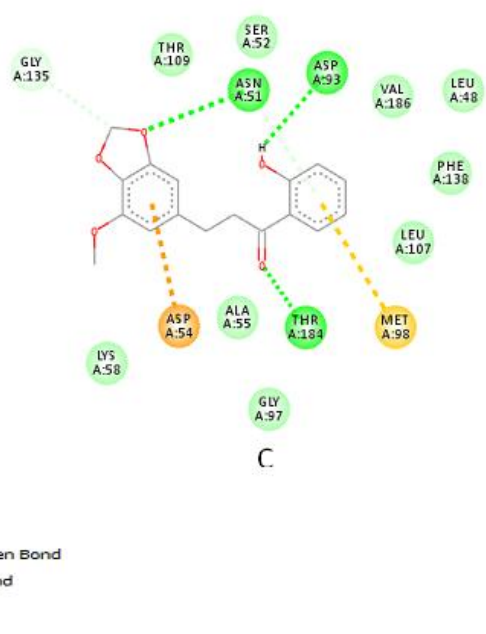

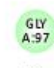

C.

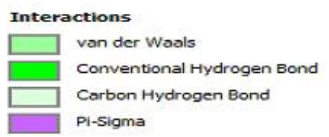

Gambar 2. A. Model interaksi ligan asli docking dengan HSP90A; B. Model interaksi Guaiacin docking dengan HSP90A; C. Model interaksi turunan miristisin 5 docking dengan HSP90A

terdapat kesamaan interaksi asam amino antara senyawa ini dengan ligan asli. Ligan ini membentuk beberapa ikatan hidrogen yang berinteraksi dengan residu Thr184 dan Asp93. Pada residu Met98 membentuk interaksi Pisulfur.

\section{Prostaglandin Synthase 2}

Hasil docking antara protein PTGS2 dengan ligan baik dari senyawa dalam minyak atsiri pala maupun senyawa turunan miristisin menunjukkan bahwa hampir semua ligan dapat berinteraksi dengan PTGS2. Ligan dengan nilai binding affinity paling kecil dan memiliki model interaksi terbaik dapat dilihat pada tabel V.

Asam dihidroguaiaretik memiliki $\Delta \mathrm{G}_{\text {bind }}$ sebesar -8,1 kkal/mol dan menempati binding pocket yang sama seperti ligan asli dan seperti pada tabel V menunjukkan bahwa senyawa ini berinteraski dengan binding pocket yang sama yang terdapat dengan beberapa residu dan cara interaksi yang identik dengan ligan asli, seperti terdapat dua ikatan hidrogen yang terjadi dengan residu Ser530, Tyr385. Rowlinson et al., (2003) menyatakan bahwa residu Ser530 dan Tyr385 penting untuk aktivitas penghambatan PTGS2. Selain ikatan hidrogen, juga terdapat ikatan Van der Walls yang turut berkonstribusi terhadap interaksi ligan dengan protein PTGS2 yang dapat terlihat pada gambar 3B. Pada gambar tersebut ditunjukkan kesamaan residu asam amino non hidrogen antara ligan kristalografi dengan ligan asli hasil docking. Kesamaan residu tersebut membentuk ikatan Pialkil antara residu Val523 dan Ala527. Penelitian sebelumnya oleh Park S et al., (1998) telah membuktikan bahwa Asam dihidroguaiaretik yang diisolasi dari $M$. fragrans memiliki efek cytotoxic pada sel kanker sevara in vitro dengan nilai IC50 0,21 mikromol.

Ligan uji turunan miristisin 13 merupakan senyawa terbaik pertama berdasarkan nilai $\Delta \mathrm{G}_{\text {bind }}$ yaitu sebesar $-8,7$ $\mathrm{kkal} / \mathrm{mol}$, senyawa ini memiliki energi yang lebih kecil dari Asam dihidroguaiaretik dan menempati binding pocket yang sama seperti 
Alfian Bagas Pratama, et al

Tabel V. Hasil senyawa docking molekuler terhadap protein PTGS2

\begin{tabular}{|c|c|c|c|c|}
\hline \multirow{2}{*}{ Senyawa } & \multirow{2}{*}{$\begin{array}{c}\Delta \mathbf{G}_{\text {binding }} \\
\text { (kkal/mol) }\end{array}$} & \multirow{2}{*}{ SD } & \multicolumn{2}{|c|}{ Insteraksi residu AA } \\
\hline & & & Hidrogen & Non-hidrogen \\
\hline Ligan asli & $-9,0$ & 0 & Ser530, Tyr385 & $\begin{array}{c}\text { Leu531, Ala527, Val349, } \\
\text { Val523, Leu352 }\end{array}$ \\
\hline Dihydroguaiaretic Acid & $-8,1$ & 0 & $\begin{array}{c}\text { Arg120, Ser530 } \\
\text { Tyr385 }\end{array}$ & $\begin{array}{l}\text { Val523, Ala527, Gly526, } \\
\text { Leu352 }\end{array}$ \\
\hline Turunan miristisin 13 & $-8,7$ & 0 & - & $\begin{array}{l}\text { Val523, Val349, Ala527, } \\
\text { Leu352 }\end{array}$ \\
\hline Turunan miristisin 4 & $-8,6$ & 0,1 & - & $\begin{array}{l}\text { Leu352, Gly56, Val523, } \\
\text { Ala527, Leu359, Leu531, } \\
\text { Val349 }\end{array}$ \\
\hline
\end{tabular}

Keterangan: cetak tebal merupakan kesamaan residu asam amino ligan uji terhadap ligan asli

Tabel VI. Hasil senyawa docking molekuler terhadap protein DHODH

\begin{tabular}{|c|c|c|c|c|}
\hline \multirow{2}{*}{ Senyawa } & \multirow{2}{*}{$\begin{array}{c}\Delta \mathrm{G}_{\text {binding }} \\
\text { (kkal/mol) }\end{array}$} & \multirow{2}{*}{ SD } & \multicolumn{2}{|c|}{ Insteraksi residu AA } \\
\hline & & & Hidrogen & $\begin{array}{l}\text { Non-hidrogen } \\
\end{array}$ \\
\hline Ligan Asli & $-12,0$ & 0,0 & Tyr356, Thr63 & $\begin{array}{l}\text { Thr360, Ala55, Leu359, Ala59, } \\
\text { Tyr38, Leu42, Pro364 }\end{array}$ \\
\hline Macelignan & $-10,4$ & 0,0 & Ala96, Gln47 & $\begin{array}{c}\text { Tyr147, Val134, Tyr356, Ala55, } \\
\text { Thr360, Val143 }\end{array}$ \\
\hline Dihydroguaiaretic Acid & $-9,3$ & 0,3 & Thr63, Tyr356 & $\begin{array}{l}\text { Pro364, Phe98, Leu359, Ala59, } \\
\text { Thr360, Ala55 }\end{array}$ \\
\hline Turunan miristisin 6 & $-10,7$ & 0,1 & Ser305 & $\begin{array}{c}\text { Ala55, Ala59, His56, Thr360, } \\
\text { Val143 }\end{array}$ \\
\hline Turunan miristisin 5 & $-10,6$ & 0,1 & Gln47 & Thr360, Ala59, Ala55, Val143 \\
\hline
\end{tabular}

Keterangan: cetak tebal merupakan kesamaan residu asam amino ligan uji terhadap ligan asli

ligan asli, seperti yang terlihat pada gambar 3C. Sayangnya, residu Tyr385 dan Ser530 yang penting untuk aktivitas penghambatan PTGS2 hanya berinteraksi secara Van der Waals dengan ligan ini. Membentuk interaksi Pi-alkyl dengan residu Val349, Ala527, dan Leu352 serta interaksi Pi-sigma pada residu Val523.

Pada ligan uji turunan miristisin 4 merupakan senyawa terbaik kedua berdasarkan urutan nilai $\Delta \mathrm{G}$ bind yaitu sebesar $-8,6 \mathrm{kkak} / \mathrm{mol}$ sama halnya dengan kedua ligan diatas, senyawa ini juga menempati binding site yang sama dengan ligan asli. Ditunjukkan pada gambar 3D ligan uji ini juga tidak ditemukan ikatan hidrogen dengan residu asam amino pada binding site. Residu Tyr385 dan Ser530 yang penting untuk aktivitas penghambatan PTGS2 hanya berinteraksi secara Van der Waals dengan ligan ini. Kesamaan residu dengan ligan asli yaitu membentuk interaksi Pi-alkyl pada residu Val523, Ala527, dan Leu53.

Namun berdasarkan data interaksi terjadi keterulangan interaksi antara struktur siklis utama pada 3 senyawa uji dengan asam amino Ala527 dan Val523 pada ligan asli residu ini berinteraksi pada cincin aromatis benzen dari ligan asli

\section{DHODH}

Menurut Sven C et al., (2019) residu asam amino yang terlibat langsung dalam interaksi dengan ligan melalui ikatan hidrogen langsung yaitu dengan Tyr356, Thr360 dan Gln47. Dan memiliki interaksi hidrofobik yang luas dengan sejumlah besar residu non-polar yaitu Tyr38, Leu42, Met43, Leu46, Leu50, Leu58, Ala59, Phe62, Leu67, Leu68, Pro69, Met111, Leu359, dan Pro353. Struktur kristal juga memprediksi ikatan hidrogen non klasik antara gugus hidroksil dari Thr63 (donor ikatan H) dan fluor dari gugus terminal fenil (akseptor ikatan $\mathrm{H}$ ).

Hasil visualisasi pada ligan uji terhadap protein DHODH yang memiliki kesamaan residu asam amino yang berinteraksi baik secara hidrogen maupun non-hidrogen ditunjukkan pada tabel VI. 

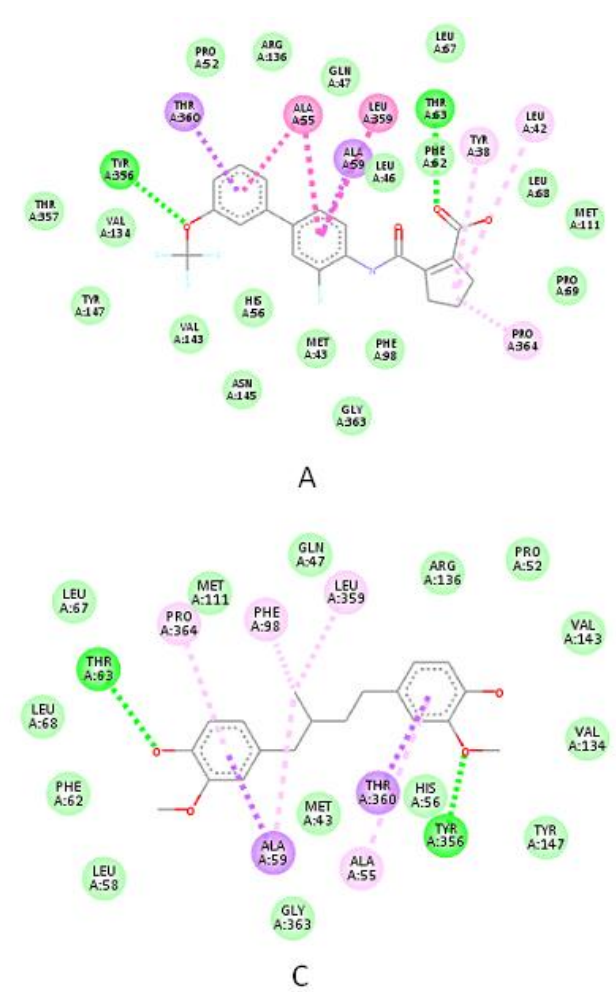

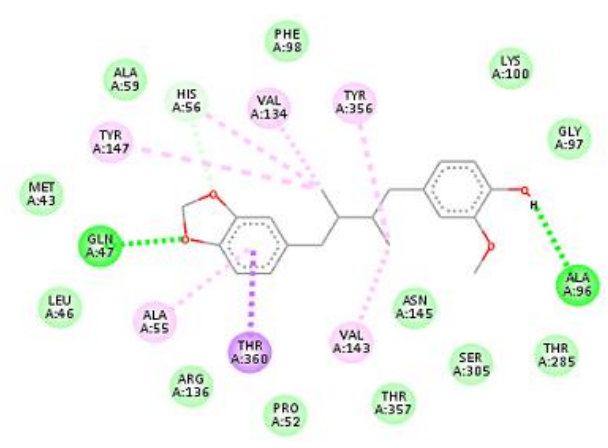

B

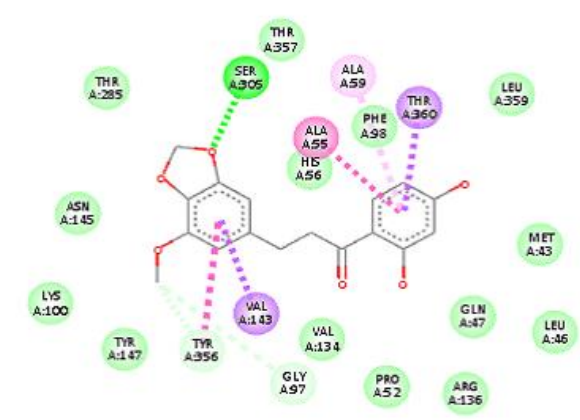

D

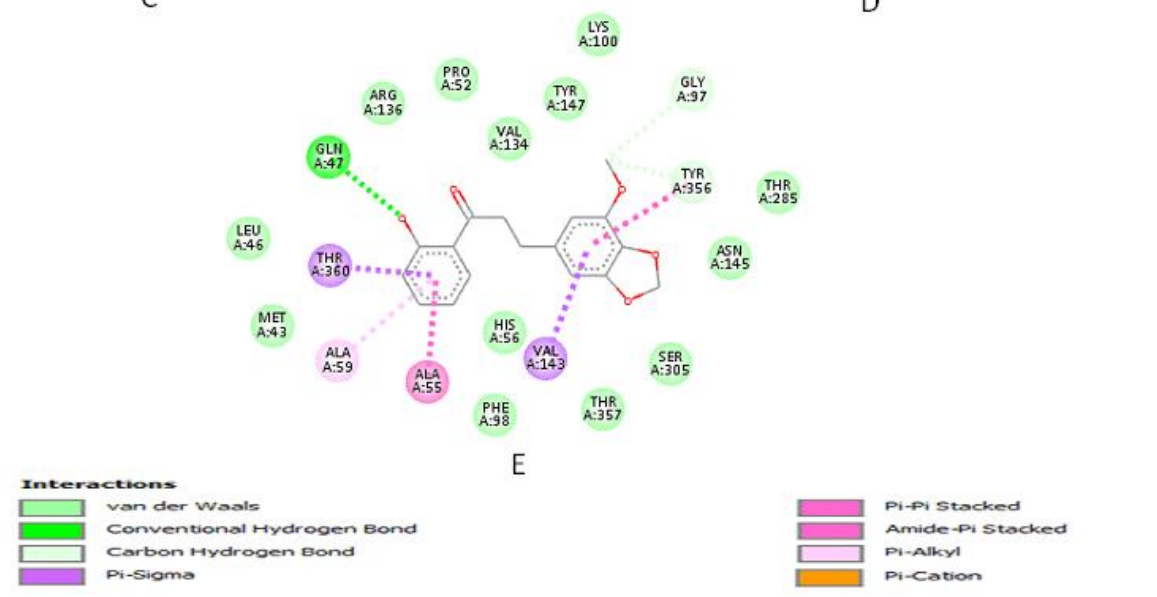

Gambar 4. A. Model interaksi ligan asli docking dengan DHODH; B. Model interaksi macelignan docking dengan DHODH; C. Model interaksi Asam dihidroguaiaretik docking dengan DHODH; D. Model interaksi turunan miristisin 6 docking dengan DHODH; E. Model interaksi turunan miristisin 5 docking dengan DHODH

Ligan uji macelignan $(-10,4 \mathrm{kkal} / \mathrm{mol})$ memiliki nilai energi binding yang kecil dan menempati binding pocket yang sama seperti ligan asli dan seperti pada tabel VI menunjukkan bahwa senyawa ini berinteraski dengan binding pocket yang sama yang terdapat dengan beberapa residu dan cara interaksi yang identik dengan ligan asli. Residu asam amino pada ligan uji tersebut tidak membentuk ikatan hidrogen yang sama dengan ligan asli melainkan ikatan non-hidrogen. Namun, pada gambar 4B ditunjukan macelignan berinteraksi dengan residu Gln47 secara ikatan hidrogen, walaupun interaksi dengan Gln47 tidak terdapat pada ligan asli, Menurut Sven C et al., (2019) Gln47 juga merupakan salah satu residu pada binding pocket yang berperan dalam penghambatan protein target. Kesamaan membentuk residu 
lainnya yaitu pada ikatan P-sigma dengan residu Thr360 serta interaksi Amide-Pi stacked dengan residu Ala55. Penelitian sebelumnya oleh Thi Van Thu Le et al., (2017) telah membuktikan bahwa macelignan yang diisolasi dari $M$. fragrans memiliki efek cytotoxic pada sel kanker secara in vitro dengan nilai IC50 6,63 $\mu \mathrm{g} / \mathrm{mL}$.

Asam dihidroguaiaretik menempati binding pocket yang sama seperti ligan asli dan terdapat ikatan hidrogen dengan Thr63 dan Tyr356 sama seperti pada ligan asli. Asam dihidroguaiaretik memberikan skor docking cukup tinggi pada protein target DHODH yaitu sebesar $-9,3 \mathrm{kkal} / \mathrm{mol}$. Selain memiliki model interaksi terbaik dengan DHODH, asam dihidroguaiaretik juga memiliki model interaksi terbaik di PTGS2. Kesamaan residu lain yaitu membentuk interaksi Pi-sigma pada residu Ala59 dan Thr360 serta interaksi Pi-alkyl pada residu Pro364 seperti yang terlihat pada gambar 4C.

Seperti yang terlihat gambar $4 \mathrm{D}$ dan $4 \mathrm{E}$, ligan uji turunan miristisin $6(-10,7 \mathrm{kkal} / \mathrm{mol})$, dan ligan uji turunan miritisin $5 \quad(-10,6$ $\mathrm{kkal} / \mathrm{mol}$ ) yang memiliki nilai energi binding yang cukup kecil mendekati skor ligan asli membentuk residu asam amino yang berperan seperti ligan asli yaitu Tyr356. Namun, residu asam amino pada kedua ligan uji tersebut tidak membentuk ikatan hidrogen melainkan ikatan non-hidrogen. Akan tetapi, pada gambar 19 diperlihatkan bahwa ligan uji turunan miristisin 5 berinteraksi dengan residu Gln47 secara ikatan hidrogen yang juga merupakan salah satu residu pada binding pocket yang berperan dalam penghambatan protein target. Kesamaan residu lain pada ke dua liga uji ini yaitu membentuk interaksi Pi-sigma pada residu Thr360, interaksi Pi-stacked pada residu Ala55, serta interaksi Pi-alkyl pada residu Ala59.

Bila diperhatikan pada gambar 4D dan 4E memiliki struktur yang hampir sama dengan penambahan donor gugus $O$ pada struktur benzen, namun memiliki ikatan dengan residu yang sedikit berbeda satu sama lain, hal ini disebabkan karena perbedaan konformasi ligan. Jembatan etilen tunggal senyawa bisa berotasi bebas membuat banyaknya konformasi yang terbentuk memungkinkan ligan untuk memiliki konfrmasi yang paling stabil pada protein targetnya.

Berdasarkan docking molekuler liganligan tersebut memiliki potensi untuk dapat menghambat Heat Shock Protein 90A, Prostaglandin synthase 2, Dihydroorotate dehidrogenase hal ini dapat berkorelasi dengan aktivitas sitotoksiknya terhadap sel kanker kulit.

\section{KESIMPULAN}

Pertama, HSP90A, PTGS2, dan DHODH diprediksi sebagai target molekuler potensial serta memiliki interaksi yang baik terhadap kandungan senyawa dalam minyak atsiri pala dan senyawa turunan miristisin sebagai target terapi kanker kulit. Kedua, Guaiacin, Asam dihidroguaiaretik, macelignan, dan 3 turunan kalkon miristisin diprediksi memiliki pola interaksi yang baik terhadap target protein molekuler kanker kulit secara studi molekuler docking.

\section{SARAN}

Pertama, perlu dilakukan penelitian lebih lanjut mengenai analisis gugus fungsi yang terlibat dalam setiap interaksi guna mengetahui sisi aktif senyawa yang diteliti dan dapat digunakan sebagai acuan untuk modifikasi struktur menjadi senyawa yang lebih potein. Kedua, perlu dilakukan studi lebih lanjut terkait farmakofor senyawa yang dilanjutkan dengan desain senyawa analog untuk meningkatkan aktivitasnya.

\section{UCAPAN TERIMAKSIH}

Penulis mengucapkan terimakasih kepada dosen pembimbing, keluarga, temanteman dan semua pihak yang telah sangat membantu dalam penelitian ini.

\section{DAFTAR PUSTAKA}

Agusta A. 2000. Komponen kimia minyak atsiri pala maba (Myristica succedanea). Majalah farmasi Indonesia 11:103-110.

AlSaher MA et al., 2016. Discovery of new heat shock protein 90 inhibitors using virtual co-crystallized pharmacophore generation. J Enzyme Inhib Med Chem 31:64-77.

Brenner M, Hearing VJ. 2008. The protective role of melanin against UV damage in human skin. Photochem Photobiol 84:539-49.

Brooijmans N. 2009. Docking metods, ligan design, and valdating data sets in the structural genomics era. 11:635-663. 
Editor: Jenny Gu dan Philip E. Bourne. Structural Bioinformatics, Second Edistion.

Chen SJ dan Ren LJ. 2014. Identification of a Potential Anticancer Target of Danshensu by Inverse Docking. Asian Pac J Cancer Prev 15:111-

Cole JC, Taylor R. 2005. Comparing ProteinLigand Docking Progam is Difficult. PubMed Protein 60: 325-32.

Cosconati S et al.,2010. Virtual Screening with AutoDock: Theory and Practice. Expert Opin Drug Discov 5:597-607

D'Orazio J, Jarrett S, Amaro-Ortiz A, Scott T. 2013. UV radiation and the skin. Int J Mol Sci 14: 12-48. DOI: 10.3390/ijms140612222

Dallakyan S, dan Olson AJ. 2015. SmallMolecule Library Sreening by Docking with PyRx. Hal. 243-250. Dalam Jonathan E. Hempel et al., Chemical Biology: Methode and Protocols, Methods in Molecular Biology 1263.

Diyah NW, Siswandono, Suko H, Bambang TP. 2013. Pemodelan Molekul Dan Hubungan Kuantitatif Struktur Aktivitas Sitotoksik Turunan Benzoilurea Sebagai Antitumor. Berkala Ilmiah Kimia Farmasi 2: 2

Drie JH. 2005. Pharmacophore-Base Virtual Screening: A Practical Prespective. Di dalam: J, Alvarez, \& B. Shoichet, Virtual Screening in Drug Discovery (p.169). Boca Raton: CRS Press

Fang Y et al., 2016. Geaux dock: accelerating structur-base virtual screening with heterogeneous computing. Plos One 11:1-29.

Fikry MA. 2014. Studi penambatan molekul senyawa-senyawa flavonoid dari buah mengkudu (Morinda citrifolia L) pada perosome proliferator-activated receptor-gamma (PPAR $\gamma$ ) [Skripsi]. Jakarta: UIN Syarif Hidayatullah.

Forli S. et al., 2016. Computational proteinligan docking and virtual drug screening with the AutoDock suit. Nature Protocols 11:905-919.

Hosseini Mohsen et al., 2019. UVB Induced DHODH Upregulation is Driven by STATB, is a Promising Targed for Chemopreventivation and Combnation Therapy of Photocaranogenesis. Oncogenesis. 8:52

Morris G.N dan Lim Wilby M. 2008. Molecular docking. Methods in Molecular Biology. 443: 365-382.

Phosrithong N dan Ungwitayatorm J. 2010. Molecular docking study on anticancer activity of plant-derived natural products. Medicinal Chemistry Research 19: 817-835.

Piaru SP et al., 2012. Antioxidant and antiangiogenic activities of the essential oils of Myristica fragrans and Morinda citrofolia. Asian Pacific Journal of Tropical Medicine 294-298.

Rowlinson SW et al., 2003. A novel mechanism of cyclooxygenase-2 inhibition involving interactions with Ser-530 and Tyr-385. J Biol Chem. 278(46).

Suthagar et al., 2012. Antioxidant and antiangiogenic activities of the essential oils of Myristica fragrans and Morinda citrifolia. Asian Pacific Journal of Tropical Medicine 294-298.

Young DW et al., 2007. Integrating HighContent Screening and Ligan-Target Prediction to Identify Mechanism of Action. Nat Chem Bio 4: 59-68. 